\title{
Exiguobacterium indicum sp. nov., a psychrophilic bacterium from the Hamta glacier of the Himalayan mountain ranges of India
}

\author{
Preeti Chaturvedi and S. Shivaji \\ Centre for Cellular and Molecular Biology, Uppal Road, Hyderabad 500 007, India
}

Correspondence
S. Shivaji
shivas@ccmb.res.in

The genus Exiguobacterium was created by Collins et al. (1983) to accommodate Gram-positive, non-spore-forming, facultatively anaerobic, alkaliphilic bacteria isolated from potato-processing effluent (Gee et al., 1980). Since then, nine species have been described: Exiguobacterium aurantiacum (Collins et al., 1983), Exiguobacterium undae and Exiguobacterium antarcticum (Fruhling et al., 2002), Exiguobacterium oxidotolerans (Yumoto et al., 2004), Exiguobacterium aestuarii and Exiguobacterium marinum (Kim et al., 2005), Exiguobacterium mexicanum and Exiguobacterium artemiae (Lopez-Cortes et al., 2006) and Exiguobacterium acetylicum (which was transferred from the genus Brevibacterium; Farrow et al., 1994). In the present study, strain HHS $31^{\mathrm{T}}$ was isolated from the melt water of the Hamta glacier located at a height of $4270 \mathrm{~m}$ above sea level in the Himalayan mountain ranges of India. The meltwater sample yielded about $2 \times 10^{4}$ c.f.u. $\mathrm{ml}^{-1}$ and the pure colonies represented 26 different morphotypes (Shivaji et al., 2005a). Representative strains from each morphotype were then tentatively identified, using their $16 \mathrm{~S}$ rRNA gene

\footnotetext{
The GenBank/EMBL/DDBJ accession number for the 16S rRNA gene sequence of strain $\mathrm{HHS} 31^{\top}$ is AJ846291.

Strain $\mathrm{HHS} 31^{\top}$ and various Exiguobacterium species are compared in a table of fatty acid compositions and a neighbour-joining phylogenetic tree available as supplementary material in IJSEM Online.
}

sequences (Shivaji et al., 2005a), as being closely related to Pseudomonas meridiana (GenBank accession no. AJ537602), Pseudomonas antarctica (AJ537601), Pseudomonas veronii (AY267192), Pseudomonas migulae (AY047218), Pseudomonas fluorescens (AY538263), Pseudomonas lini (AY035996), Pseudomonas jessinii (AY391278), Serratia marcescens (AF076038), Janthinobacterium lividum (AY247410), Bacillus subtilis (AY672765), Hafnia alvei (AY572428), E. acetylicum (AY297792) and Pedobacter cryoconitis (AJ585231) (Shivaji et al., 2005a). Two of the strains, HHS $11^{\mathrm{T}}$ and HHS $22^{\mathrm{T}}$, were identified as representing novel species of Dyadobacter and Pedobacter, namely Dyadobacter hamtensis (Chaturvedi et al., 2005) and Pedobacter himalayensis (Shivaji et al., 2005a). In the present study, strain HHS $31^{\mathrm{T}}$, a Gram-positive, motile, non-sporeforming, rod-shaped bacterium, was identified, using polyphasic taxonomy, as representing a novel species of the genus Exiguobacterium.

Strain HHS $31^{\mathrm{T}}$ was isolated by plating $1 \mathrm{ml}$ glacial water on nutrient agar plates $[0.5 \%(\mathrm{w} / \mathrm{v})$ peptone, $0.3 \%(\mathrm{w} / \mathrm{v})$ beef extract, $0 \cdot 5 \%(\mathrm{w} / \mathrm{v}) \mathrm{NaCl}$ and $1 \cdot 5 \%(\mathrm{w} / \mathrm{v})$ agar, $\mathrm{pH} 7 \cdot 0]$ that were then incubated at $22{ }^{\circ} \mathrm{C}$ for 3 days. Nutrient agar medium was also used for maintaining strain HHS $31^{\mathrm{T}}$ and for determining growth at various temperatures $(5,10,15$, $22,28,37$ and $\left.40{ }^{\circ} \mathrm{C}\right)$, at different $\mathrm{pH}$ values $(\mathrm{pH} 4,6,7,8,10$ and 11) and in the presence of various concentrations of 
$\mathrm{NaCl}(5,10,12$ and $15 \%)$ (Shivaji et al., 1989). The buffers

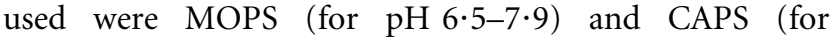
$\mathrm{pH} 9 \cdot 7-11 \cdot 1)$. Phenotypic characteristics such as colony morphology, cell morphology, motility, various enzyme activities (as listed in Table 1) and sensitivity to antibiotics at $22^{\circ} \mathrm{C}$ were ascertained using standard methods (Lanyi, 1987; Smibert \& Krieg, 1994). Gas production was determined according to the method of Hugh \& Leifson (1953). For acid production, the medium used was phenol red agar base $(\mathrm{pH} 7 \cdot 4)$ containing proteose peptone $(1 \%)$, beef extract $(0 \cdot 1 \%), \mathrm{NaCl}(0 \cdot 5 \%)$, phenol red $(0 \cdot 0025 \%)$ and agar $(1 \cdot 8 \%)$. Minimal medium $\left[\mathrm{K}_{2} \mathrm{HPO}_{4}, 1 \cdot 05 \%(\mathrm{w} / \mathrm{v})\right.$; $\mathrm{KH}_{2} \mathrm{PO}_{4}, 0.45 \%(\mathrm{w} / \mathrm{v}) ;\left(\mathrm{NH}_{4}\right)_{2} \mathrm{SO}_{4}, 0.1 \%(\mathrm{w} / \mathrm{v}) ;$ agar, $1.5 \%(\mathrm{w} / \mathrm{v})]$ was used to evaluate the ability of the culture to assimilate various carbon compounds, including amino acids $(0 \cdot 5 \%, \mathrm{w} / \mathrm{v})$, when provided as the sole carbon source. Fatty acid methyl esters were prepared according to the method of Sato \& Murata (1988) and analysed by GC (Shivaji et al., 2004, 2005b, c). The G+C content of the DNA was determined by the spectrophotometric method (Shivaji et al., 1989). Isoprenoid quinones were extracted according to the method described by Collins et al. (1977), separated by HPLC and identified as described by Reddy et al. (2003). Peptidoglycan was prepared and analysed according to the method described by Komagata \& Suzuki (1987). DNA-DNA hybridization was performed by using the membrane filter method (Tourova \& Antonov, 1987), as described previously (Shivaji et al., 1992). E. acetylicum DSM $20416^{\mathrm{T}}$, E. undae DSM $14481^{\mathrm{T}}$, E. antarcticum DSM $14480^{\mathrm{T}}$ and E. oxidotolerans JCM $12280^{\mathrm{T}}$ were used as reference strains in studies relating to morphology, biochemical characteristics and the identification of fatty acids.

To establish the phylogenetic position of strain HHS $31^{\mathrm{T}}$, DNA was purified and the $16 \mathrm{~S}$ rRNA gene was amplified and sequenced as described previously (Shivaji et al., 2000). The almost-complete rRNA gene sequence (1503 bases) was manually aligned with those of closely related species by using CLUSTAL W (Thompson et al., 1994) (see Supplementary Fig. S1 available in IJSEM Online) and phylogenetic affiliations were inferred using SEQBOOT, DNADIST and neighbour-joining from PHYLIP (Felsenstein, 1993). The Kimura two-parameter method was used for DNA distance calculations (Kimura, 1980), and bootstrap values were generated for 1000 replications of the data. In all cases, the input order of species added to the topology being constructed was randomized with the jumble option, with a random seed of 7 and 10 replications. Majority-rule (50\%) consensus trees were constructed (Page, 1996).

The phenotypic and chemotaxonomic characteristics of strain HHS $31^{\mathrm{T}}$ are presented in the species description and in Table 1 (and in Supplementary Table S1 available in IJSEM Online). Strain HHS $31^{\mathrm{T}}$, which is Gram-positive, motile, rod-shaped, non-spore-forming, alkaliphilic, possesses MK-7 and MK- 8 as the major menaquinones, has the Lys-Gly peptidoglycan type and has a DNA G + C content of
$48 \mathrm{~mol} \%$, is similar to species of the genus Exiguobacterium (Collins et al., 1983; Farrow et al., 1994; Fruhling et al., 2002; Yumoto et al., 2004; Kim et al., 2005; Lopez-Cortes et al., 2006). Phylogenetic analysis based on the $16 \mathrm{~S}$ rRNA gene sequence $(1480 \mathrm{nt})$ and performed with the neighbourjoining algorithm further confirms the affiliation of HHS $31^{\mathrm{T}}$ with the genus Exiguobacterium. All of the reported species of Exiguobacterium formed two distinct clusters, as reported previously (Lopez-Cortes et al., 2006; Kim et al., 2005). Strain HHS $31^{\mathrm{T}}$ forms part of one of these clusters, which includes E. acetylicum DSM $20416^{\mathrm{T}}$, E. oxidotolerans JCM $12280^{\mathrm{T}}$, E. undae DSM $14481^{\mathrm{T}}$, E. antarcticum DSM $14480^{\mathrm{T}}$ and E. artemiae DSM $16484^{\mathrm{T}}$ (Supplementary Fig. S1). The coherence of the cluster is obvious from the high bootstrap value ( $>78 \%$ ) between strains in the cluster. The remaining strains, namely $E$. aurantiacum NCDO $2321^{\mathrm{T}}$, E. mexicanum DSM $16483^{\mathrm{T}}$, E. marinum DSM $16307^{\mathrm{T}}$ and E. aestuarii DSM $16306^{\mathrm{T}}$, form a separate clade.

Using GeneTool 1.0 (http://www.biotools.com), the degrees of affiliation (i.e. 16S rRNA gene sequence similarity) between HHS $31^{\mathrm{T}}$ and reported species of Exiguobacterium were $93.6 \%$ (E. aurantiacum NCDO $2321^{\mathrm{T}}$; GenBank accession no. X70316), $94 \%$ (E. aestuarii TF-16 ${ }^{\mathrm{T}}$; AY594264), $94 \cdot 2 \%$ (E. marinum $\mathrm{TF}-80^{\mathrm{T}}$; AY594266), $94 \cdot 2 \%$ (E. mexicanum DSM $16483^{\mathrm{T}}$; AM072764), $96 \cdot 2 \%$ (E. artemiae DSM $16484^{\mathrm{T}}$; AM072763), 97.4\% (E. undae DSM $14481^{\mathrm{T}}$; AJ344151), 97.9\% (E. oxidotolerans $\mathrm{T}-2-2^{\mathrm{T}}$; $\mathrm{AB} 105164), 98 \%$ (E. antarcticum DSM $14480^{\mathrm{T}} ; \mathrm{AJ} 297437$ ) and $98.9 \%$ (E. acetylicum IFO $12146^{\mathrm{T}}$; D55730). Thus, strain HHS $31^{\mathrm{T}}$, which exhibits $>97 \% 16 \mathrm{~S}$ rRNA gene sequence similarity with the type strains of E. acetylicum, $E$. antarcticum, E. oxidotolerans and E. undae, needs to be differentiated from these four species to merit membership of a novel species. At the whole-genome level, as determined by DNA-DNA hybridization when strain HHS $31^{\mathrm{T}}$ was radioactively labelled, the strain showed DNA-DNA hybridization values with E. oxidotolerans JCM $12280^{\mathrm{T}}$, E. acetylicum DSM $20416^{\mathrm{T}}$, E. undae DSM $14481^{\mathrm{T}}$ and $E$. antarcticum DSM $14480^{\mathrm{T}}$ of $50,63,67$ and $28 \%$, respectively. However, when E. oxidotolerans JCM $12280^{\mathrm{T}}$, E. acetylicum DSM $20416^{\mathrm{T}}$ and E. undae DSM $14481^{\mathrm{T}}$ were labelled and used for DNA-DNA hybridization with HHS $31^{\mathrm{T}}$, the relatedness values were 49,56 and $60 \%$, respectively. Furthermore, HHS $31^{\mathrm{T}}$ differs from the closest species, E. oxidotolerans, E. acetylicum, E. undae, E. antarcticum and 'Exiguobacterium sibiricum' (Rodrigues et al., 2006), with respect to a number of phenotypic characteristics (Table 1) and also exhibits significant quantitative differences in fatty acid composition (Supplementary Table S1). The predominant fatty acids are iso- $\mathrm{C}_{15: 0}(48 \cdot 7 \%)$ and iso- $\mathrm{C}_{17: 0}(43 \%)$, which together constituted $\sim 92 \%$ of the total fatty acid content. These two fatty acids were also predominant in the remaining five species of Exiguobacterium (Supplementary Table S1). However, an interesting feature is that the combined levels of iso- $\mathrm{C}_{15: 0}(12-48 \cdot 7 \%)$ and iso- $\mathrm{C}_{17: 0}(12-43 \%)$ were highest in E. indicum HHS $31^{\mathrm{T}}$, E. oxidotolerans JCM 


\section{Table 1. Phenotypic characteristics that differentiate strain $\mathrm{HHS} 31^{\top}$ and related type strains}

Strains: 1, strain HHS $31^{\mathrm{T}}$; 2, E. acetylicum DSM $20416^{\mathrm{T}}$; 3, E. oxidotolerans JCM $12280^{\mathrm{T}}$; 4, E. antarcticum DSM $14480^{\mathrm{T}}$; 5, E. undae DSM $14481^{\mathrm{T}} ; 6$, 'E. sibiricum' DSM 17290. Data for all strains except 'E. sibiricum' DSM 17290 (Rodrigues et al., 2006) are from this study unless indicated. All of the strains shown are motile, Gram-positive, rod-shaped, do not form endospores, grow at temperatures between 10 and $30^{\circ} \mathrm{C}$ (with optimum growth at $25^{\circ} \mathrm{C}$ ), tolerate up to $5.8 \% \mathrm{NaCl}$, grow in peptone, do not grow at $\mathrm{pH} 4$, grow at $\mathrm{pH} 6-10$, utilize dextrin and are positive for catalase, oxidase, $\beta$-galactosidase, arginine dihydrolase, ornithine decarboxylase and in the Voges-Proskauer test. All are negative for urease, $\mathrm{H}_{2} \mathrm{~S}$ production, in the indole test and for acid production from D-sorbitol, L-melibiose, D-lactose, L-arabinose and L-xylose. All utilize D-glucose, sucrose, glycerol and thioglycolate but do not utilize L-sorbose, D-arabinose, L-arabinose, D-lactose, Dadonitol, hydroxybutyric acid, dextran or sodium propionate. All are sensitive to the following antibiotics ( $\mu \mathrm{g})$ : tobramycin (15), lomefloxacin (30), roxithromycin (30), ciprofloxacin (30), lincomycin (15), cefotaxime (30), cefazolin (30), kanamycin (30), novobiocin (30), chloramphenicol (30), ampicillin (25), tetracycline (30), streptomycin (25), erythromycin (15), bacitracin (10), gentamicin G (30), polymyxin B (50), oleandomycin (15), spectinomycin (100), rifampicin (25) and carbenicillin (100). +, Positive; -, negative; ND, not done/no data available; +/-, variable reaction; $\mathrm{w}$, weakly positive.

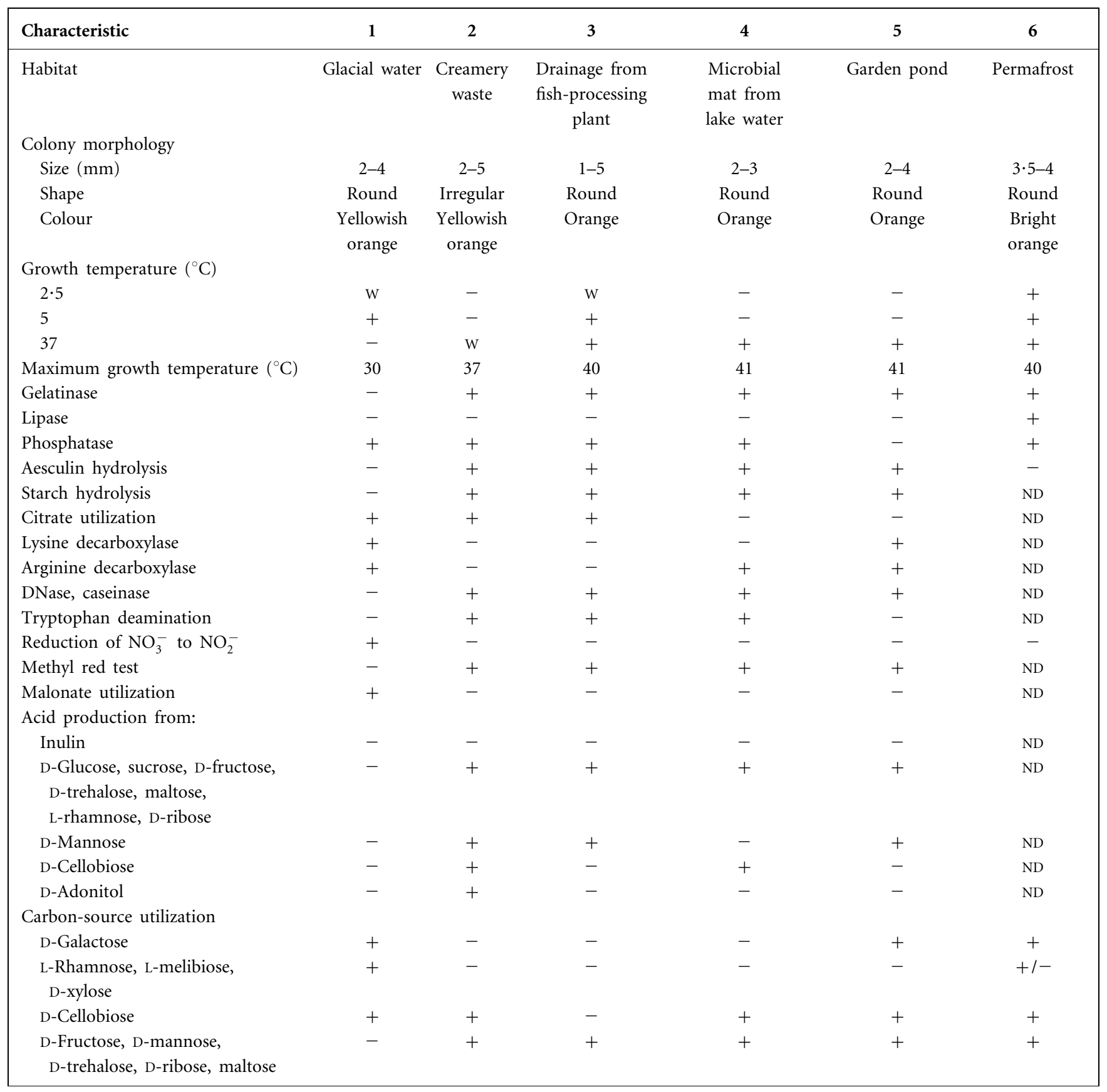


Table 1. cont.

\begin{tabular}{|c|c|c|c|c|c|c|}
\hline Characteristic & 1 & 2 & 3 & 4 & 5 & 6 \\
\hline L-Xylose & + & - & - & - & - & ND \\
\hline D-Mannitol & - & + & + & - & + & + \\
\hline D-Raffinose & + & - & - & + & + & + \\
\hline Lactic acid, D-sorbitol, dulcitol & + & - & - & - & - & - \\
\hline Fumaric acid & + & - & - & - & - & ND \\
\hline D-Melezitose & - & + & - & - & - & $+1-$ \\
\hline Polyethylene glycol & + & - & - & - & + & ND \\
\hline $\mathrm{N}$-Acetylglucosamine & - & - & - & - & - & + \\
\hline Citric acid, sodium acetate & + & - & - & + & + & $\mathrm{ND}$ \\
\hline Potassium acetate & + & - & - & - & + & $\mathrm{ND}$ \\
\hline Cellulose & - & - & - & - & + & $\mathrm{ND}$ \\
\hline Starch & - & + & + & + & + & + \\
\hline Inulin, myo-inositol & + & - & - & - & - & - \\
\hline Pyruvate & - & + & + & + & + & + \\
\hline Glycogen & + & - & - & + & + & $\mathrm{ND}$ \\
\hline Methyl $\alpha$-D-mannoside & - & + & - & + & - & - \\
\hline Methyl $\alpha$-D-glucoside & - & + & + & - & + & - \\
\hline Methyl $\alpha$-D-galactoside & + & - & - & - & - & - \\
\hline Methyl $\beta$-D-galactoside & + & - & - & - & - & + \\
\hline Arbutin & + & - & + & + & + & + \\
\hline Salicin & - & + & - & - & + & + \\
\hline Amygdalin & - & - & + & + & + & + \\
\hline Xylitol, L-fucose & - & + & - & - & - & - \\
\hline L-Malic acid & + & - & - & - & - & $+1-$ \\
\hline Erythritol & + & - & + & - & + & $\mathrm{ND}$ \\
\hline Sodium gluconate, 5-ketogluconate & + & - & - & - & - & - \\
\hline Sodium fumarate, sodium formate & + & - & - & + & - & ND \\
\hline Sodium succinate & + & - & - & - & + & + \\
\hline$\gamma$-Glucuronic acid & + & - & - & - & + & $\mathrm{ND}$ \\
\hline$\alpha$-Ketoglutaric acid & + & - & - & - & + & - \\
\hline Valeric acid & + & - & - & + & - & + \\
\hline \multicolumn{7}{|l|}{ Amino acids used } \\
\hline L-Glycine & + & - & - & - & + & ND \\
\hline $\begin{array}{l}\text { L-Ornithine, L-valine, L-threonine, } \\
\text { L-arginine, L-proline, L-histidine }\end{array}$ & + & - & - & + & + & $\mathrm{ND}$ \\
\hline L-Alanine & + & - & - & + & + & - \\
\hline L-Leucine, L-tyrosine & + & + & - & + & + & ND \\
\hline $\begin{array}{l}\text { L-Isoleucine, L-lysine, L-glutamine, } \\
\text { L-methionine }\end{array}$ & + & - & + & + & + & ND \\
\hline L-Serine & + & - & + & - & + & $+1-$ \\
\hline L-Glutamic acid & + & - & - & + & - & $+1-$ \\
\hline L-Aspartic acid & + & - & + & - & + & $\mathrm{ND}$ \\
\hline L-Asparagine & + & - & - & + & + & + \\
\hline L-Cysteine & - & - & - & + & + & ND \\
\hline L-Phenylalanine & - & - & - & - & - & ND \\
\hline L-Tryptophan & + & - & - & + & - & ND \\
\hline L-Creatinine & + & - & - & - & - & ND \\
\hline \multicolumn{7}{|l|}{ Antibiotic tolerance $(\mu \mathrm{g} \text { per disc) })^{*}$} \\
\hline Norfloxacin (10) & $\mathrm{R}$ & s & s & s & s & ND \\
\hline Amikacin $(30)$ & $\mathrm{R}$ & s & s & s & s & $\mathrm{ND}$ \\
\hline Nitrofurantoin (300) & $\mathrm{R}$ & s & s & s & s & ND \\
\hline Cotrimoxazole (25) & $\mathrm{R}$ & s & s & s & s & ND \\
\hline Amoxycillin (30) & $\mathrm{R}$ & s & s & s & s & $\mathrm{ND}$ \\
\hline Nalidixic acid $(30)$ & $\mathrm{R}$ & s & s & $\mathrm{s}$ & s & ND \\
\hline
\end{tabular}


Table 1. cont.

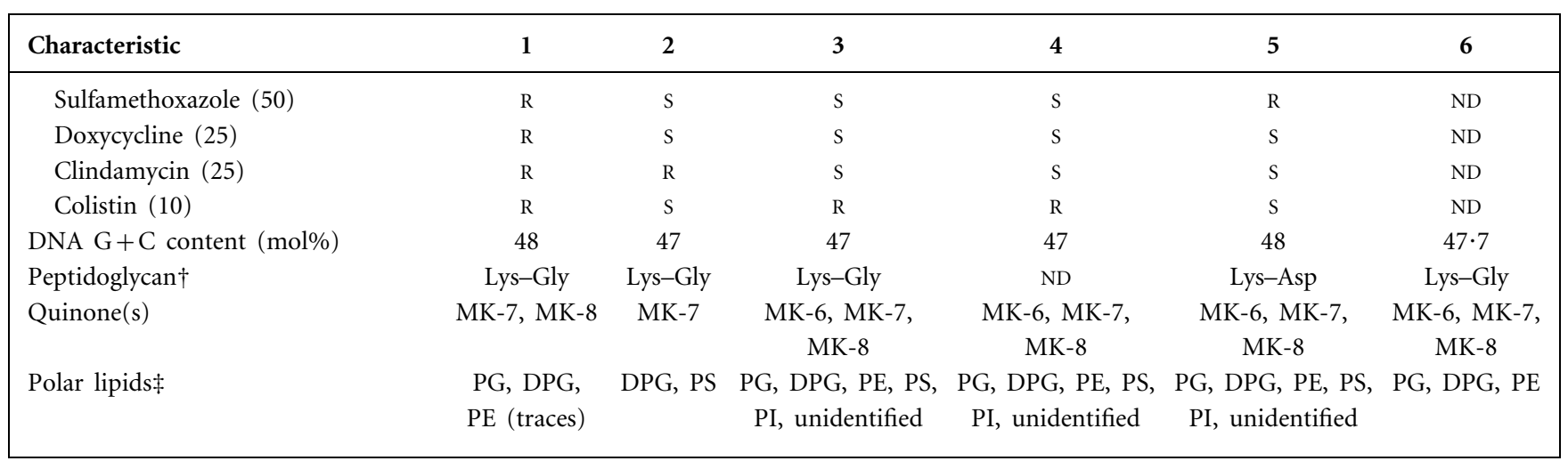

${ }^{\star} \mathrm{R}$, Resistant; $\mathrm{S}$, sensitive.

$\dagger$ Determined for HHS $31^{\mathrm{T}}$, E. acetylicum DSM $20416^{\mathrm{T}}$ and E. undae DSM $14481^{\mathrm{T}}$ in this study. Peptidoglycan compositions for E. oxidotolerans JCM $12280^{\mathrm{T}}$, E. antarcticum DSM $14480^{\mathrm{T}}$ and 'E. sibiricum' DSM 17290 were taken from Yumoto et al. (2004), Fruhling et al. (2002) and Rodrigues et al. (2006), respectively.

‡DPG, Diphosphatidylglycerol; PE, phosphatidylethanolamine; PG, phosphatidylglycerol; PI, phosphatidylinositol; PS, phosphatidylserine.

$12280^{\mathrm{T}}$ and 'E. sibiricum' DSM 17290. These three species grow at $2.5^{\circ} \mathrm{C}$, unlike the other species. Thus, these fatty acids (iso- $\mathrm{C}_{15: 0}$ and iso- $\mathrm{C}_{17: 0}$ ) may be required for growth at low temperatures. According to the criteria for species discrimination (Stackebrandt \& Goebel, 1994), strain HHS $31^{\mathrm{T}}$, which exhibits $<70 \%$ relatedness at the DNA-DNA level with the type strains of E. oxidotolerans, E. antarcticum, E. acetylicum and E. undae (the most closely related species) and which also differs phenotypically from these four species, represents a novel species of the genus Exiguobacterium, for which the name Exiguobacterium indicum sp. nov. is proposed.

\section{Description of Exiguobacterium indicum sp. nov.}

Exiguobacterium indicum (in'di.cum. L. neut. adj. indicum Indian, pertaining to India).

Cells are aerobic, Gram-positive, motile and rod-shaped $(2.3 \mu \mathrm{m}$ long and $0.52 \mu \mathrm{m}$ wide). Stationary-phase cells are coccobacilli. Colonies $(2-4 \mathrm{~mm})$ on nutrient agar are round, shiny, irregular, elevated and orange-coloured after $24 \mathrm{~h}$ at $22^{\circ} \mathrm{C}$. No spores are observed. Grows at $5-30{ }^{\circ} \mathrm{C}$ and at $\mathrm{pH} 6-10$. The optimum temperature and $\mathrm{pH}$ for growth are $25^{\circ} \mathrm{C}$ and $\mathrm{pH} 7 \cdot 0$. Tolerates $5 \cdot 8 \% \mathrm{NaCl}$ and also grows in the absence of salt. Colonies are yellowish orange in colour. The pigment is soluble in chloroform and exhibits multiple absorption maxima at 408, 434, 460 and $495 \mathrm{~nm}$. Positive for catalase, oxidase, $\beta$-galactosidase, phosphatase, arginine dihydrolase, lysine decarboxylase, ornithine decarboxylase, arginine decarboxylase, citrate utilization, malonate utilization, in the Voges-Proskauer test and for reduction of nitrate to nitrite. Negative for urease, lipase, gelatinase, DNase, caseinase, tryptophan deamination, indole production, in the methyl red test, for $\mathrm{H}_{2} \mathrm{~S}$ production and for hydrolysis of aesculin and starch hydrolysis. Utilizes D-glucose, D-galactose, D-rhamnose,
L-melibiose, D-cellobiose, sucrose, D-xylose, L-xylose, Draffinose, glycerol, lactic acid, fumaric acid, $\mathrm{N}$-acetylglucosamine, D-sorbitol, dulcitol, polyethylene glycol, citric acid, sodium acetate, potassium acetate, inulin, dextrin, myoinositol, glycogen, sodium thioglycolate, methyl $\alpha$-Dgalactoside, methyl $\beta$-D-galactoside, arbutin, malic acid, erythritol, sodium gluconate, sodium fumarate, sodium formate, sodium succinate, $\gamma$-glucuronic acid, $\alpha$-ketoglutaric acid, valeric acid, 5-ketogluconate, L-glycine, Lornithine, L-alanine, L-valine, L-leucine, L-isoleucine, Lserine, L-threonine, L-lysine, L-arginine, L-glutamic acid, L-aspartic acid, glutamine, L-asparagine, L-methionine, Ltyrosine, L-tryptophan, L-proline, L-histidine and L-creatinine, but not L-sorbose, $\mathrm{L}$ - or $\mathrm{D}$-arabinose, $\mathrm{D}$-fructose, $\mathrm{D}$ mannose, D-trehalose, D-mannitol, D-ribose, D-lactose, Dadonitol, maltose, D-melezitose, hydroxybutyric acid, dextran, sodium propionate, cellulose, starch, pyruvate, methyl $\alpha$-D-mannoside, methyl $\alpha$-D-glucoside, salicin, amygdalin, xylitol, L-fucose, L-cysteine or L-phenylalanine. Negative for acid production from inulin, D-glucose, sucrose, D-fructose, D-sorbitol, L-melibiose, D-lactose, Dtrehalose, maltose, L-rhamnose, D-mannose, L-arabinose, Lxylose, D-ribose, D-cellobiose and adonitol. Resistant to discs containing the following antibiotics $(\mu \mathrm{g})$ : norfloxacin (10), cotrimoxazole (25), clindamycin (25), doxycycline (25), sulfamethoxazole (50), amoxicillin (30), amikacin (30), nalidixic acid (30), nitrofurantoin (300) and colistin (10). Sensitive to the following antibiotics $(\mu \mathrm{g})$ : tobramycin (15), lomefloxacin (30), roxithromycin (30), ciprofloxacin (30), penicillin (10), cefoperazone (75), vancomycin (30), cefuroxime (30), lincomycin (15), cefotaxime (30), cefazolin (30), kanamycin (30), novobiocin (30), chloramphenicol (30), ampicillin (25), tetracycline (30), streptomycin (25), erythromycin (15), bacitracin (10), gentamicin G (30), polymyxin B (50), oleandomycin (15), spectinomycin (100), rifampicin (25) and carbenicillin (100). Major respiratory 
quinones are MK-7 and MK-8. Peptidoglycan is of the LysGly type. Phosphatidylglycerol and diphosphatidylglycerol are the main phospholipids; minute amounts of phosphatidylethanolamine are also present. The DNA G $+\mathrm{C}$ content is $48 \cdot 0 \mathrm{~mol} \%$. The fatty acids present are iso- $\mathrm{C}_{13: 0}(0 \cdot 2 \%)$, iso- $\mathrm{C}_{15: 0}(48 \cdot 7 \%)$, iso- $\mathrm{C}_{16: 0}(3 \cdot 0 \%), \mathrm{C}_{16: 1}(0 \cdot 3 \%)$, iso$\mathrm{C}_{17: 0}(43 \cdot 0 \%)$, anteiso- $\mathrm{C}_{17: 0}(0 \cdot 3 \%)$ and $\mathrm{C}_{18: 1}(2 \cdot 0 \%)$.

The type strain, HHS $31^{\mathrm{T}}\left(=\mathrm{LMG} 23471^{\mathrm{T}}=\right.$ IAM $\left.15368^{\mathrm{T}}\right)$, was isolated from melt water from the Hamta glacier located at a height of $4279 \mathrm{~m}$ above sea level in the Himalayan mountain ranges of India.

\section{Acknowledgements}

We thank the Department of Biotechnology of the Government of India (New Delhi, India) for a research grant awarded to S. S. We are grateful to Dr Jean Euzéby for helping us with the naming of the novel species.

\section{References}

Chaturvedi, P., Reddy, G. S. N. \& Shivaji, S. (2005). Dyadobacter hamtensis sp. nov., from Hamta glacier, Himalayas, India. Int J Syst Evol Microbiol 55, 2113-2117.

Collins, M. D., Pirouz, T., Goodfellow, M. \& Minnikin, D. E. (1977). Distribution of menaquinones in actinomycetes and corynebacteria. J Gen Microbiol 100, 221-230.

Collins, M. D., Lund, B. M., Farrow, J. A. E. \& Schleifer, K. H. (1983). Chemotaxonomic study of an alkalophilic bacterium Exiguobacterium aurantiacum gen. nov., sp. nov. J Gen Microbiol 129, 2037-2042.

Farrow, J. A. E., Wallbanks, S. \& Collins, M. D. (1994). Phylogenetic interrelationships of round-spore-forming bacilli containing cell walls based on lysine and the non-spore-forming genera Caryophanon, Exiguobacterium, Kurthia and Planococcus. Int J Syst Bacteriol 44, 74-82.

Felsenstein, J. (1993). PHYLIP (phylogeny inference package), version 3.5c. Distributed by the author. Department of Genome Sciences, University of Washington, Seattle, USA.

Fruhling, A., Schumann, P., Hippe, H., Straubler, B. \& Stackebrandt, E. (2002). Exiguobacterium undae sp. nov. and Exiguobacterium antarcticum sp. nov. Int J Syst Evol Microbiol 52, 1171-1176.

Gee, J. M., Lund, B. M., Metcalf, G. \& Peel, J. L. (1980). Properties of a new group of alkalophilic bacteria. J Gen Microbiol 117, 9-17.

Hugh, R. \& Leifson, E. (1953). The taxonomic significance of fermentative versus oxidative metabolism of carbohydrates by various gram negative bacteria. $J$ Bacteriol 66, 24-26.

Kim, I.-G., Lee, M.-H., Jung, S.-Y., Song, J. J., Oh, T.-K. \& Yoon, J.-H. (2005). Exiguobacterium aestuarii sp. nov. and Exiguobacterium marinum sp. nov., isolated from a tidal flat of the Yellow Sea in Korea. Int J Syst Evol Microbiol 55, 885-889.

Kimura, M. (1980). A simple method for estimating evolutionary rates of base substitutions through comparative studies of nucleotide sequences. J Mol Evol 16, 111-120.

Komagata, K. \& Suzuki, K. (1987). Lipid and cell wall analysis in bacterial systematics. Methods Microbiol 19, 161-206.

Lanyi, B. (1987). Classical and rapid identification methods for medically important bacteria. Methods Microbiol 19, 1-67.
Lopez-Cortes, A., Schumann, P., Pukall, R. \& Stackebrandt, E. (2006). Exiguobacterium mexicanum sp. nov. and Exiguobacterium artemiae sp. nov., isolated from the brine shrimp Artemia franciscana. Syst Appl Microbiol 29, 183-190.

Page, R. D. M. (1996). TREEVIEW: an application to display phylogenetic trees on personal computers. Comput Appl Biosci 12, 357-358.

Reddy, G. S. N., Matsumoto, G. I. \& Shivaji, S. (2003). Sporosarcina macmurdoensis sp. nov., from a cyanobacterial mat sample from a pond in the McMurdo Dry Valleys, Antarctica. Int J Syst Evol Microbiol 53, 1363-1367.

Rodrigues, D. F., Goris, J., Vishnivetskaya, T., Gilichinsky, D., Thomashaw, M. F. \& Tiedje, J. M. (2006). Characterization of Exiguobacterium isolates from the Siberian permafrost. Description of Exiguobacterium sibiricum sp. nov. Extremophiles 10, 285-294.

Sato, N. S. \& Murata, N. (1988). Membrane lipids. Methods Enzymol 167, 251-259.

Shivaji, S., Shyamala Rao, N., Saisree, L., Reddy, G. S. N., Seshu Kumar, G. \& Bhargava, P. M. (1989). Isolates of Arthrobacter from the soils of Schirmacher Oasis, Antarctica. Polar Biol 10, 225-229.

Shivaji, S., Ray, M. K., Shyamala Rao, N., Saisree, L., Jagannadham, M. V., Seshu Kumar, G., Reddy, G. S. N. \& Bhargava, P. M. (1992). Sphingobacterium antarcticus sp. nov., a psychrotrophic bacterium from the soils of Schirmacher Oasis, Antarctica. Int J Syst Bacteriol 42, 102-106.

Shivaji, S., Bhanu, V. N. \& Aggarwal, R. K. (2000). Identification of Yersinia pestis as the causative organism of Plague in India as determined by $16 \mathrm{~S}$ rDNA sequencing and RAPD-based genomic fingerprinting. FEMS Microbiol Lett 189, 247-252.

Shivaji, S., Reddy, G. S. N., Raghavan, P. U. M., Sarita, N. B. \& Delille, D. (2004). Psychrobacter salsus sp. nov. and Psychrobacter adeliensis sp. nov. isolated from fast ice from Adelie Land, Antarctica. Syst Appl Microbiol 27, 628-635.

Shivaji, S., Chaturvedi, P., Reddy, G. S. N. \& Suresh, K. (2005a). Pedobacter himalayensis sp. nov., from the Hamta glacier located in the Himalayan mountain ranges of India. Int J Syst Evol Microbiol 55, 1083-1088.

Shivaji, S., Suresh, K., Chaturvedi, P., Dube, S. \& Sengupta, S. (2005b). Bacillus arsenicus sp. nov., an arsenic-resistant bacterium isolated from a siderite concretion in West Bengal, India. Int J Syst Evol Microbiol 55, 1123-1127.

Shivaji, S., Gupta, P., Chaturvedi, P., Suresh, K. \& Delille, D. (2005c). Marinobacter maritimus sp. nov., a psychrotolerant strain isolated from sea water off the subantarctic Kerguelen islands. Int J Syst Evol Microbiol 55, 1453-1456.

Smibert, R. M. \& Krieg, N. R. (1994). Phenotypic characterization. In Methods for General and Molecular Bacteriology, pp. 607-654. Edited by P. Gerhardt. Washington, DC: American Society for Microbiology.

Stackebrandt, E. \& Goebel, B. M. (1994). A place for DNA-DNA reassociation and 16S rRNA sequence analysis in the present species definition in bacteriology. Int J Syst Bacteriol 44, 846-849.

Thompson, J. D., Higgins, D. G. \& Gibson, T. J. (1994). ClUSTAL W: improving the sensitivity of progressive multiple sequence alignment through sequence weighting, position-specific gap penalties and weight matrix choice. Nucleic Acids Res 22, 4673-4680.

Tourova, T. P. \& Antonov, A. S. (1987). Identification of microorganisms by rapid DNA-DNA hybridization. Methods Microbiol 19, 333-355.

Yumoto, I., Narisawa, M. H., Hirota, K., Shingyo, T., Takebe, F., Nodasaka, Y., Matsuyama, H. \& Hara, I. (2004). Exiguobacterium oxidotolerans sp. nov., a novel alkaliphile exhibiting high catalase activity. Int J Syst Evol Microbiol 54, 2013-2017. 